\title{
Monitoring Media Crisis
}

\author{
A Decade of Stories about \\ Unemployment in Helsingin Sanomat
}

\author{
SAnNa VALtonen
}

\begin{abstract}
Media space will always be contested space. This itself is a good reason for monitoring what takes place in that arena (Eldridge 1999).
\end{abstract}

Common values bind societies together. In the 90s, Finland has gone through a set of changes that endeavor traditional Finnish values. Seemingly, the most drastic changes were external. Finland became a member of the European Union and was thus defined as 'western' more strongly than ever before. At the same time, however, the cultural and political meaning of 'west' has become more equivocal and vague (see e.g. Alasuutari \& Ruuska 1999). The internal changes, too, have been dramatic. Finland faced a deep economic crisis, that had effects in all aspects of Finnish society. In three years (1990-1993) the unemployment rate went from $3,5 \%$ up to $20 \%$ (Kiander \& Vartia 1998). In addition to and because of the depression, there has been considerable re-organization going on: fields, that have traditionally been controlled by the state have been denationalized and the line of activities still governed by the state have acquired new ways of functioning from business world. There has also been a number of cut-backs in social security benefits (Uusitalo 1997). From the point of view of Finnish people though, it seems that, the economic crises and the massive unemployment were the most meaningful changes (e.g., Kivikuru 1996, Vähätalo 1998).

The influences of the economic crisis of the 90s were not only economical in their nature. The recession had an impact on political, social and mental dimensions. The social atmosphere in Finland has changed: in addition to politics, the media and the sphere of cultural practices have had to adapt their functions to new circumstances. This has had an effect on citizens' everyday life and conceptions of the world and future.

Political and economic discourses were astonishingly homogenous all along the recession (Vartiainen, 1993, 62), which was reflected on the media discourse as well (Ilmonen 1993, 7-9). In the media, political decisions were presented as the 'only real possibilities', and within the same discourse, the role of the audience was turned from citizen into spectator. Public discussions about the recession and its consequences failed in creating self-understanding within the society: media discourse left citizens in the arms of economic irrevocabilities. Media discourse was also said to reflect different kinds of post modernisms, into which the fast tempo of social and political changes in the beginning of the 90 s has coaxed political discourse. Even though the post modernisms might plumb the spirit or atmosphere of the society, they have not provided any structural explanations to understand societal developments (e.g., Ilmonen 1993, 11). 


\section{... and the Media}

Appreciated media scholars have described journalism as 'the sense making discourse of modernity' (e.g. Schudson 1996, Ekecranz 1996). Both journalism and modernity are products of developments in European societies during the last few centuries and both of them are associated with science, industrialization, imperialism and political liberation. Today, the media and society are deeply interwoven. The media can not be reduced to spaces or arenas where cultural or political interaction is made visible, for the interaction takes place through the media: the media has become the organizational focus for an interaction of political activity (McNair 1998, 55-56), and it's hardly possible to imagine today's political life without journalism (Hartley 1996).

The media and specially news journalism serve a vital democratic function. The news construct a symbolic world that has a certification of legitimacy and that is easily available for all of us. News are a resource when people are ready to take political action. (Schudson 1996, 33) The media so add something to every story they run. When the media offer a public item of news, they confer upon it public legitimacy. They bring it out to a common public forum and instead of merely reporting an event, they amplify it. Public amplification provides a certification of importance. (ibid., 19-21)

Journalism is a privileged cultural form. It lays claim to the qualities of truthfulness and accuracy - it asks to be accepted as the 'approximation' to truth or as 'mediated reality'. The cultural power of journalism is rooted in its discursive status as truth, its ability to mobilize belief and consent through the telling of stories which are credible because they are journalistic. The producers of journalism can not take this credibility for granted, and therefore they must constantly assert and reassert their status through conventions and practices that signify the 'believability' to the audience. It is, at the same time, an ideological force communicating not only the 'facts' but also a way of understanding and making sense of the facts. And since there are several 'understandings' to facts, journalism is thus an arena for struggle between competing ways of sense-making. (see e.g., McNair 1998, 5-8, 56-57)

Amongst writings of Finnish media scholars over the years, it has been possible to detect a negative tone towards theorizing the relationship between media and democracy (e.g., Luostarinen 1993, also Curran 1991). There have been claims, that people do not use the media because of its societal dimension, but because its good entertainment: media use has been connected conceptually with patterns of consumption, and watching the news has been almost equated to watching serials and soap. On the other hand, journalism has been inspected as a machinery through which the elite is able to articulate and reproduce its status and power. And the 'from few to many' -structure of modern journalism has been seen more suitable for informing people than for societal discussion.

To me it seems, though, that Finns, for example, have held to their habit of regular newspaper reading in their daily life because journalism somehow meets their life world and interests towards the society (not to say they would not be entertained by the same newspapers). The defining and concluding developments and phenomena of social reality which takes place within the media discourse is meaningful from the point of view of (imagined) communities and cultural identities. Texts represent the reader's possibility to become involved with shared social reality. As members of (imagined) communities, news make us note same issues at same time, and often from the same perspectives. Therefore media studies, and even content analysis, should pose questions about whether there is an active attempt to create a public sphere, where interests of different groups of people can meet. 
I believe that, the public sphere and imagined communities are different sides of the same coin, and that as well as different communities, the public is to be found from the texts and stories of the media. To study text comes from the idea, that within text, we can see the culmination point of the difficult relationship between action and society (structure). When focusing on society, action looks like its structural outcome, and when focusing an action, society seems to be a limiting factor. According to Pietilä and Sondermann (1994, 5-6, 73), when you look at mass communication as action materializing in text, texts come to represent both action and societal structures. Thus, when seeking the changing material media provided for building imagined communities during the crisis, news is essential.

\section{About Data and Method}

The extensive quantitative data includes all stories about both unemployment and work/ working life published in Helsingin Sanomat (HS) and its weekly and monthly appendixes (Kuukausiliite, NYT-liite) during 1988-1997. HS is an interesting source of data for number of reasons. Firstly, in spite of discourses stressing globalization or localization, there certainly was a 'national' level in the crisis. No matter the stress and pressure recent developments might have put on the nation state system, modern societies are still built on nation state and its political organization. Accordingly, mass communication has been nationally organized (e.g., national broadcasting companies). In Finland, the newspapers have been regional, and only afternoon papers and HS have claimed being 'national'. Their 'national', however, has been criticized for being more or less symbolic. On one hand, globalization and its various consequences call forth new kinds of approaches to 'national'. On the other hand, there is a vivid discussion about growing importance of 'local' (everyday practices, experiences etc.) in formation of cultural identities. The importance of locality and local public sphere is by no means diminishing, and there are interpretations about the growing importance of local during the crisis. (e.g., Moring 1999)

From the framework of my interests, this criticism, however, should be faced with another set of arguments. In spite of varying local consequences of the recession, there was still a crisis that encountered the whole nation. Because of the crisis people's experiences changed in similar ways throughout Finland, and the changes penetrated places and spaces as well as social layers. The public discussions generated by the recession produced a lot of national level definitions and conclusions, and even after the recession, it seems that, at least amongst Finnish social scientists, there is an ever-increasing discussion about Finland, nation state and Finnishness going on. Many interpretations see the crises as a touchstone of national storylines, and a test of media's democratic dimensions (Kantola 1997). Even though HS is not a national medium neither by circulation ${ }^{1}$ nor by content, it is the biggest and probably the most influential print medium in Finland. In its discourse, HS does not address a region like the regional newspapers do. Also HS has a special role in Finnish political culture and in formation of discussions of social issues. For journalists working in other media, HS is a source of information as well as a framework and measure stick for their own work (e.g., Pietilä \& Sondermann 1994, 78 and Koistinen 1998). Therefore the 'us' HS constructs is of importance when thinking about the structures of belonging in Finland.

The method used in the analysis was quantitative content analysis. It is described as a method seeking to produce objective, quantitative and justifiable description of the explicit content (e.g., Fiske 1992, 179, Riffe \& al., 1998). In other words, by monitoring 
content I tried to produce valid and repeatable connections and relationships between phenomena in the data. The objectivity of these relationships is another story: to me the codes and modes of classifying in media studies are not unambiguous enough to make talk about objectivity possible. Media monitoring goes beyond merely recording content - it is characterizing something according to a criterion. Thus monitoring is judgemental by character and can therefore be considered a form of media criticism. The knowledge produced is always defined by the criteria used in producing it.

The data consists of a total of 31401 stories. Because of the amount of research material, stories were collected on grounds of headlines and coded on grounds of glancing them through. In a typical news story the headline reduces the central content and forms the first meeting point for the story and its reader. In most cases, the form of a headline is argumentative in addition to its pithyness; it leads to the foot of story's interpretation of the issue and in some cases it also presents the grounds for the interpretation in condensed form. (Kunelius 1996, 276) ${ }^{2}$ In Det redigerade samhället, Ekecrantz \& Olsson (1994, 4-6) pointed out, that modern journalism is a mass phenomenon, a machinery producing massive amounts of texts for wide audiences, and that, it is thoroughly problematic to separate journalism's qualitative and quantitative dimensions. Also the emphasis on events, that seems to dominate modern journalism is misleading, for all the phases in the production of (news)journalism are regulated by tighter or looser sets of routines. The choice of headlines as the unit of study in the quantitative analysis is also justified from this point of view of routines and continuity.

In spite of its problematic aspects, content analysis as a choice of method is justified, when you look at the size of the data: I can not figure out any other way of going it through systematically. In addition, content analysis gives a possibility to produce a 'big picture' or a general description of the object of study. As McQuail (1999) puts it, monitoring is 'not an academic luxury, but a vital function, for it serves as a means to audit democracy'. It is possible to point out when and in what quantities certain phenomena of working life were discussed during the recession, and by whom were these issues brought up with. I assume, that the economic crisis had an impact on discussions about social issues; their volume, topics and debaters. On grounds of quantitative content analysis it is possible to locate different debates and social actors in time dimension, and point out specially interesting moments or life-spans of interesting themes for further analysis.

\section{Media Monitoring as Constructing a 'Meta-Narrative'}

Writing about unemployment and/or the decay of work-centered welfare state is of importance from the point of view of Finnish culture, for Finnish culture has often been defined as uniform and work-centered (see e.g., Anttila 1993, Heinonen 1997, Kettunen 1997, Valtonen 1998 and 1999). When looking at the problem of unemployment from a constructionist framework, it is not only the number of the unemployed that create 'crisis', but the 'crisis' has also to do with the way unemployment is interpreted and defined. The economic crisis of the 90 s caused a tension between the traditional values of a work-centered welfare state called Finland and the 'reality' of mass unemployment. I am interested in how the tension and its dynamics was represented in the media discourse. Journalism mediates claims of social problems to masses of people. As a social actor, the media is multidimensional: on one hand, it can set out demands itself, and on the other hand, it provides an arena for demands of other social actors and their de- 
mands. The latter includes a possibility of deciding whose perspectives and demands get to be on a public agenda.

As stated before, monitoring media content is a controversial way of producing research material, but from the point of view of construction of social problems, the longitudinal content analysis makes sense. A longitudinal study of media content provides and interesting perspective to cultural transformations: the appearing of certain themes, their 'refining' into more sophisticated discussions, fading of other themes and discussions, the appearing of new 'participants' (actors, sources) in defining and discussing social problems and the disappearing of some others can be inspected as ways of constructing and coping with social problems on a societal level. Blumer (1971) talks about the natural history of social problems - some stay in the public debate constantly, some disappear to be born again later in some other form/context. It is justifiable to talk about 'life spans' of social problems (Hakkarainen 1998, 202). Monitoring media content in its political, cultural and historical context can be a relevant tool for understanding both the construction of the problem itself and the double role of the media as the arena of constructing social problems and the mediator of interpretations and claims criss-crossing the same arena ${ }^{3}$.

Blumer comes forward with a 5-stage model on how this 'natural history' of a social problem is constructed. The first phase, the emergence of a social problem refers to social actors starting to demand attention to an issue. The second phase, legitimatization of a social problem, takes place, when the problem is widely recognized and discussed. If the importance of processing the issue is admitted widely enough, the third phase (mobilization of action) might be actualized. This is when communal resources are channeled for solving the problem, and the public debate is lively and targeted. Blumer suggests, that what is decided upon the problem depends upon this phase, for the next phase is institutionalization of the problem, ensued by the possible implementation of the official plan. When talking about persistent or long-term problems like unemployment, the processes of defining may recur, and the definitions may transform over time. I try to point out some changes of trends and re-definitions that took place during the crisis of the $90 \mathrm{~s}$.

I divided stories into generic categories crudely on grounds of 'who speaks'. This categorization is unorthodox and perhaps too rough, but with it I have tried to illustrate an actor-based organization of public discussion. Within categories of 'news' and 'columns, editorials etc.' there are of course more sophisticated journalistic tools, that offer journalists different ways of tackling the topic. To my study purposes, however, it seems sufficient to reside in this crude categorization. A 'theme', in its turn, is the total of stories, that deal with the same issue on grounds of headlines/ glancing over. Themes can be looked as serials which are in some contexts included and excluded in some others from the public arena of journalistic discourse.

The first figure represent all writing about work related issues. There were an average of 9 stories in each of the 3500 HS papers published during the research period. A great deal of work related issues are institutionalized: for example the incomes policy negotiations and the collective labor agreements are reported every year as well as unemployment statistics (even though the rate of publishing statistics fastened and slowed alongside the unemployment rate).

In general, writing about work-related issues increased during the research period. On the other hand, writing about some themes vanished from the agenda during the hardest stages of the recession. This happened to debates about values in working life, job satisfaction and developing working life. The remaining stories in the mid 90s 
Figure 1. Writings about Work and Unemployment in Helsingin Sanomat 1988-1997

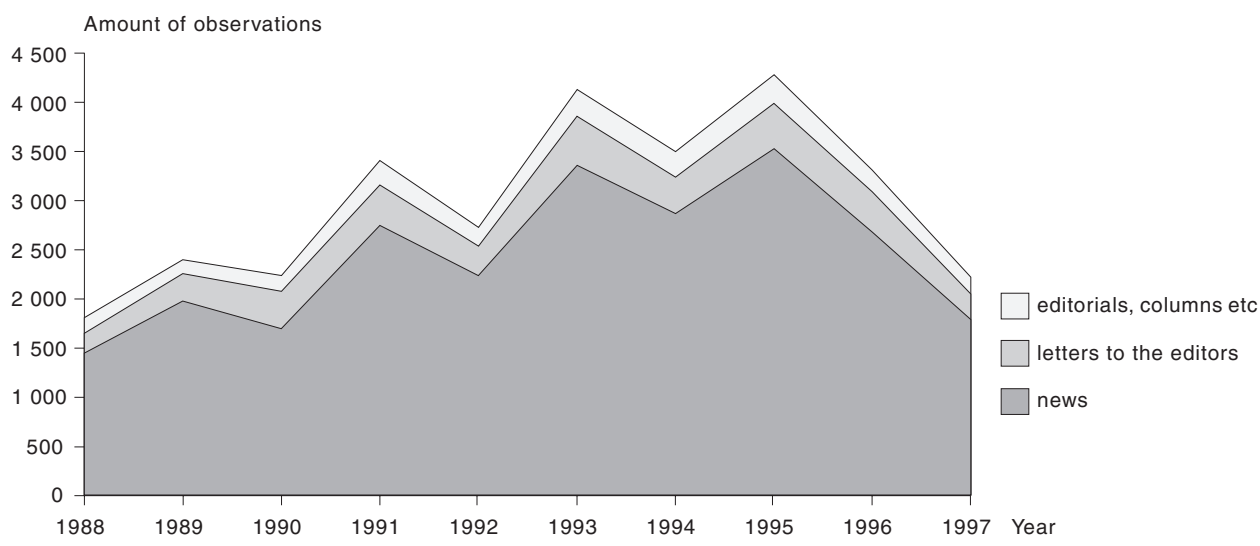

about developing working life were very different from their angle, when compared to the stories in the 80s: questions of well-being and motivation were turned into questions of cost rationality and efficiency. A good example is the switch of framework in writing about telecommuting: in both beginning and end of the research period, telecommuting was presented as a factor increasing satisfaction and motivation, but during the darkest recession, the topic found its location from the economy-section of the paper, where companies were interviewed on how much money they saved switching offices to telecommuting.

Also writing about voluntary work was practically nonexistent in the end of 80 s, but as the unemployment rate started to ascent, the writing begun. My hypotheses is that, when the crisis grew deeper, voluntary work started to look like a meaningful issue from many different frameworks. On one hand, voluntary work could be offered as a 'mediator' in conflict between the existing employment situation and the traditional values of work-centered society. On the other hand, the growing number of people living on different welfare and unemployment benefits started to make representatives of middle class (having to deal with a growing load of taxes and payments) nervous: pretensions about reciprocity in receiving benefits were put in. It is interesting to clarify the contents of the discussions and the discussants: what kind of voluntary work is suggested and for whom and by whom.

The relative proportion of letter's to the editors -writings on work-related issues grew alongside unemployment rate, but also during big strikes (nurses, firemen and bank personnel). It has been most interesting to look at quantities of letter's to the editors -writings monthly, for it seems, that when it comes to certain themes, a rush in letter's to the editors -pages leads to dealing the issues also within editorials and other comment/column material. From the point of view of the current debate about public journalism, this seems utterly interesting.

It was not, however, only the number of discussions carried on unemployment that arouse during the research period. It seems, that the threshold of being published got lower for most of the work-related themes, for when working life was in the middle of transformation, most societal actors considered it inevitable to discuss the changes. The institutionalized agenda was suddenly accompanied with a selection of new agenda of recession-related topics and themes. The public sphere of work-related issues was thus 
necessarily fragmented, and it is hard to avoid interpretations that emphasize the reactivity of the media. This reactivity of course reflected the diversity, that was characteristic to comprehension of the crisis and its impacts among politicians, economists and researchers.

Figure 2. Writings on Unemployment in Helsingin Sanomat 1988-1997

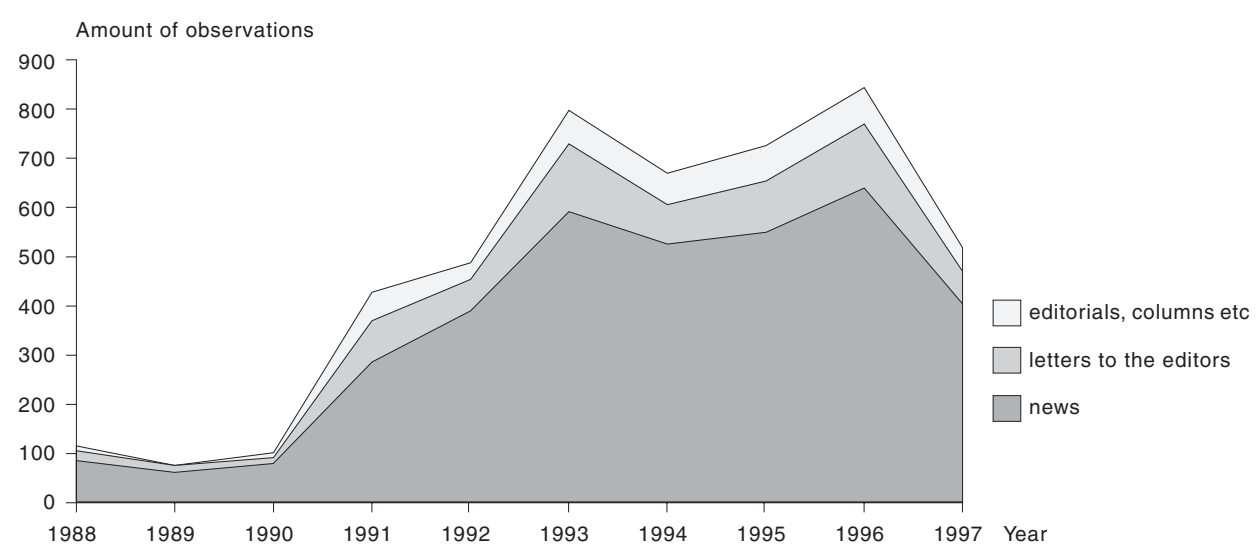

Quantitatively, writing about unemployment followed the unemployment rate with a couple of exceptions. When looking at the sum frequencies, as in figure 2, there seems to be a decline on the curve in 1994, which could be interpreted to be either wearing out of the themes and getting tired of the discussion or the shift of media-agenda caused by presidential election and the EU-referendum, or of course, both.

When looking at individual themes and their life spans during the research period, there is a bit more variation. Stories about the unemployed were common in the beginning of the decade - HS published a number of series about 'life as unemployed' in 1992-1995. In 1994, however, the angle in these stories started to shift. Earlier, the focus was on surviving strategies, everyday practices and possibilities to 'recover' etc. Around 1994 the emphasis started to be in more 'regular' news material, events, decisions and changes in policies or regulations.

In the beginning of the research period, there was just unemployment. The statistics were published twice a year, and every once in a while there was a story about unemployment as a social problem. Even when the recession started, unemployment and the unemployed were handled in the same stories - all the aspects of the problem were combined or generalized. Later, in 1992, unemployment as a theme started disperse into more specific categories. The stories started to report unemployment within a certain field, within young men, within young people in general, within aging people and within women. Long-term unemployment, social dropouts and marginalization became on agenda even later. In 1992, public discussions about adequacy or inadequacy of unemployment benefits started and were continued until the end of the research period. At the end of the period, though, the focus was on possible misuse of these benefits. Also writing about unemployment in general started to shift from describing its impacts on both the unemployed and the societal structure into speculating its costs and their equal division. These kinds of shifts and developments in the 'agenda of unemployment' undeniably tell something about changing values and hierarchies in the society. 
These results are of course very general. Particular issues would call more specificity, but even this more general form of monitoring produces something useful. Even if we might never find out the extent of influence from outside the media, we can know something about the face showing to the public. The most traditional monitoring addresses content: media's ability to report all sides of the story or all variations of the plot as well as the democracy of writing (are all groups involved in social issues given voice in the public space) (see e.g., Galtung \& Vincent 1992). When monitoring the 'form' (Galtung 1999,22 ) of the writing about unemployment, it is possible to compare the space given to journalism, commentary material and reader's voices - an issue not really tackled in this article, but both pictures 1 and 2 indicate not only the amount of 'cases' or observations, but also the volume of these three different voices.

Monitoring content should be somehow focused on special moments (elections etc.) or certain discussions (monitoring the life span of a theme) (Edwards \& al. 1999, 40). Galtung suggests comparative monitoring but not comparative only across media, but also through time $(1999,22)$. 'All around' monitoring draws attention to 'earth quake there, ban of alcohol here and a crime wave in somewhere else' and results easily in interpretations stressing the 'blurring line of news and entertainment' or the 'melding of public and private' or 'politicization of once-private affairs' (Schudson 1996, 170, also Galtung 1999). Even if these interpretations about transformations of the public sphere were right, monitoring alone can not provide straight empirical evidence, nor can it give answers to any 'why' questions. The idea behind monitoring is not theorizing, but monitoring can provide data that can serve as raw material for theories. I do believe, that even if answering a 'why-question' is not possible, selective media monitoring can help produce relevant questions for further analysis. It seems substantiated to look at some specific themes and their representation from the point of view of continuity, trying to look at what are the conditions under which a theme is taken into the sphere of the routinized gaze of journalism and how the sets of rules or conditions are re-produced and transformed over time.

\section{Monitoring the Discursive 'Us'}

The writing about unemployment and the unemployed is extremely interesting from another angle: the point of view of discursive 'us'. When circumstances in a society alter, the stories constructing (imagined) community, have to be re-produced. Constructing identity is a two-way street in the sense that, it is a process of both turning many into one (focusing on similarity and smoothing internal differences) and a process of distinguishing one from all others. In Finland, cultural identities are in close connection with the concept of work (e.g., Anttila 1993). Finns have come face to face with different kinds of crisis, smaller and greater, by increasing their work $\operatorname{load}^{4}$. It could be said, that Finland is a typical work-centered society, where the surviving of majority of the population and the uniformity of the society and its values have been connected to work and labor market. Unemployment and 'laziness' have even been seen as threats to the social system. Work is the sphere of life, where Finns have traditionally measured their value in the eyes of their co-citizens and aspired culturally valued (economic) independence, self-sufficiency and control over one's own life. In addition, in Finland work has had to do with citizenship: in many discourses, it is the working people, that construct the 'us' and people outside the labor market (e.g., the unemployed) are seen as 'others'. Therefore the massive unemployment of the 90s disconcerted not only individuals and communities, but the very basis of Finnish society. 
In post-modern societies, the concrete forms of collaboration have been replaced by ideas, principles and conceptions over which people form imagined communities (Anderson 1983, 6-12). If we assume a relation between discussions in the media and imagined communities, it is of outmost importance to study the discussions. I agree with scholars stressing the increasing importance of the media in modern society; it has not only grown in people's spare time and entertainment, but also in politics and the sphere of economy (e.g., Thompson 1995, Väliverronen 1998). I believe it is possible to study communities and their characteristics by inspecting the stories communities produce about themselves. I gather, that stories about unemployment and/or the decay of workcentered welfare society are of importance from the point of view of Finnish culture, for it has often been defined as uniform and work-centered (see e.g., Anttila 1993, Heinonen 997, Kettunen 1997, Mäkelä 1989, Renvall 1998, Valtonen 1998 and 1999). In a way, economic crisis of the 90 s challenged journalism and its ability to deal with transformations in central area of the society so, that mutual understanding remains. The 'us' in discourses of national identity and media is constructed around people working and voting and implementing all the duties and rights appertaining to the way of life of a workcentered society. The explosive growth of unemployment imposed journalistic discourse of HS a new task: if it still wished to achieve a 'national' or widest possible audience, it had to expand its us/them constructions so, that also new groups of people and ways of life could be fitted in.

As mentioned earlier, 'themes' can be looked as serials that come and go in journalistic practices. I have so far presented the historical dimension of constructing certain themes in HS. Now I wish to discuss the communal aspect of writing about a theme, starting with separating different ways of presenting a theme. Since the analysis is still based on quantitative, roughly coded data, the categorization is again as crude as possible.

In general, there were 3 ways of writing about unemployment (about ways of writing, see also Renvall \& Reunanen 1999, 85), and these three types of representing an issue position 'we' differently. There were problem-centered, administrative or process-oriented stories, in which information about unemployment was given in a form, that easily dispels political or ethical dimensions. The 'we' in these stories was 'universal' or widest possible - journalistic discourse represents all of us.

The second way of writing consisted of stories representing controversy of interests. These stories brought up the competing views and stressed struggle. The construction of 'us' varied. In some cases, the voice of the journalism was similar to one (strongest or official) point of view, whereas the other competing voices were represented somehow selfish in their struggle. In other cases, the widest possible 'us' was constructed.

Third, there were moral, ethical and scandalous stories, in which the theme was dealt with in a way that easily provokes prejudice etc. (This kind of story construction was, however, uncommon in HS.) In these stories, the changes in the us/them -construction caused by the realities of the crisis was most noticeable. It seems that a notable number of arguments in discussions about working life and especially unemployment are located in the sphere of moral (see e.g. Vähätalo 1998). In media publicity of work related issues, questions dealing with the functionality of Finnish society, reasonability and rightfulness of policies and economic decisions are central - that is questions which have to do with common values and shared conceptions of right and wrong.

One of the themes constructed also as moral or even scandalous was writing about unemployment benefits. Quantitatively, writing about unemployment benefits reached its peak as late as in 1996, when the unemployment rate had been (slowly) lowering for 
a year. I assume, that unemployment was such a painful problem from so many angles, that critical conversation about its costs was only possible after the worst was over. Before the culmination point of the unemployment rates, the stories were neutral and reporting in their character, and even though some stories about e.g., misuse of unemployment benefit were published, more critical stories remained as a side issue in the media discussion. In 1996 and 1997 as much as a fifth of all the stories about unemployment benefits and costs was about misuse. The moral (or the more traditional) aspects of unemployment gained foothold, even though moral panic forecasted by some researchers (e.g., Julkunen 1993, see also Golding \& Middleton 1980) never happened in pages of HS.

There was a change also in the positioning of the unemployed. In 1992-1995 HS published a number of series about 'life as unemployed'. In 1994, however, the angle in these stories started to shift. Earlier, the focus was on surviving strategies, everyday practices and possibilities to 'recover' etc. Around 1994 the emphasis started to be in more 'regular' news material, events, decisions and changes in policies or regulations. Significant here is, that, the unemployed formerly represented as the 'marginal' were turned into a group of social actors in the media discourse. As a hypotheses, when inspecting these discussions qualitatively, I assume, that the transformation has something to do with social moral and common values - it was impossible to repeatedly leave a fifth of working aged Finns out of 'us', so the conditions of decent citizenship were (even intentionally) expanded.

Heikki Luostarinen describes the relationship between media discourse, elites and the people aptly by using metaphors like 'doormen of public sphere' and 'repairing coefficients' (1993, 244-246). He claims, that journalists recognize their role as 'doormen of public sphere' and that they also can evaluate social groups and their abilities to function in society and influence social debates in the media. 'Repairing coefficient' are drawn from these evaluations, and with the coefficients, journalists try to distribute possibilities to take part in public debates more evenly. Luostarinen comes to argue, that, there are groups in the society like the unemployed, that are outside all coefficients. My longitudinal data shows, however, that slow changes happen, the unemployed were transferred from the margin to the active public sphere, where it is at least possible to become heard (and not only asked questions) in the media discourse and to benefit from repairing coefficients.

In different circumstances discursive landscapes grow different, and stories about 'us' as well: different actors are accepted to such stories, different conceptions of past chosen as official. The media is thus a dynamic machinery producing cultural meanings. Meanings produced within its texts are, however, not one-sided or monophonous, nor is their interpretation fixed in any way. Media discourse produces multiple social representations, multiple narrative strategies and dynamics of their mutual struggle. Media discourse is not either liberal or conservative as such, but often it strives for being 'a little bit both' in order to attract widest possible audiences.

\section{Conclusion}

Writing about work-related issues seems to have both increased and widened during the crisis - the recession forced themes which were unknown to the HS of the 80s to the agenda. It also seems, that some discussions came to stay: even if working life is discussed only a little bit more often than before the crisis, there are five times more stories about unemployment now than there were in the 80s. It seems, that after the end of 1993, 
there has been also qualitative changes in many discussions: unemployment turned into bad situation in employment (EU policy), the unemployed gained new social status, discussions about developing working life re-appeared but in slightly changed colors. In addition, the solidarity the crisis produced started to disappear, and discussions loaded with moral resentment begun.

The unemployment caused by the economic crisis has been presented both from the frameworks of despair and possibility. From both of the frames, the recession was seen as a challenge or a touchstone to welfare politics and democracy. In the media discourse however, the crisis was re-presented with generalizing figures, growth curves and percentages, but at the same time the crisis touched people's lives in different ways and levels. This made the role of the media crucial, for it provided a link between political elites and (groups of) people.

One central dimension of the media is its ability to organize social reality. Via the media, communities can point out their central events and mark their (cultural) territory. The media constructs reality from a common point of view and helps its audiences to interpret important historical and spatial dimensions (Altheide 1985). Carey $(1989,19)$ claims that journalism binds audiences into communities with narratives of consensus, which leave structures of social power visible. The media brings up issues for masses of people to be aware of at the same time. By pointing out common experiences it creates sensations of 'us' and 'them' and community. In spite of challenges from directions of globalization and/or local particularities, commonplace nationalism, national pre-political 'we' has not disappeared. Naturalized and self-evident conception of us is according to Alasuutari $(1999,134)$ something media discourse produces, reproduces and maintains unnoticed all the time.

Economic crisis of the 90 s challenged journalism and its ability to deal with transformations in central area of the society so, that mutual understandings can remains. The explosive growth of unemployment made journalistic discourse expand its us/them constructions so, that also new groups of people and ways of life could be fitted in. The life spans of themes related to working life in HS tell at least about an effort made in that direction, but it is only after qualitative text analysis of important discussions, themes and moments in the research period, that one can evaluate the limits, conditions and shifts of us/them constructions.

Heikkilä and Kunelius (1997) write, that journalism should be evaluated in terms of three concepts: access, dialogue and deliberation. When thinking of access, questions like who gets to define reality? what kinds of actors are noted in media discourse? what kinds of restrictions are set for information to become public? Become important. On grounds of my data, the economic crisis had an access-related impact on HS's agenda in the sense that the unemployed were given new space as a group and as a social actor.

The concept of dialogue, in its turn, demands questions like: in what quantities does journalism provoke social debates? how does dialogue work as a form of journalism? how relevant descriptions of reality can dialogical journalism produce? The dialogue can be 'internal' that is, happen within the stories. Then the question is about diversity of definitions (Heikkilä \& Kunelius 1997, 9, also Curran 1991). A sub-study on misuse of social security benefits conducted with Mika Renvall (Renvall \& Valtonen 1999) shows, that questions challenging nation's morals and common values are dealt with broadminded manner and diversity of actors. Predictions about moral panics and media panics given in the middle of the crisis did not materialize, and it seems that, in post modern society, it is no longer possible to pursue one uniform identity by defining/labeling some 
group/s as other. On the other hand, it is possible, that the solidarity and mutual understanding that has prevailed vanishes, when the recession in public sector continues while the economy is blooming.

The dialogue can also refer to the relation between journalism and its audience. Good journalism should be able resonate with its readers. When thinking about the deeper meaning of the public, that is, for example, about creating space for new kind of social debate or political culture, one drifts into questions of deliberation. To my understanding, the most fruitful aspect of the concept of deliberation is its assumption, that everyone has know-how and capability when it comes to social and political. Thus journalism could learn from the people, if it only would stop locating people 'outside' the society and start taking people inside the processes of journalism (also Heikkilä \& Kunelius 1996, 91).

There was an attempt to be seen in HS to bring up citizens perceptions of the recession, but when looking at citizens as actor in the data, it is clear that ordinary people have a minuscule role in the discourse of journalism. Tuchman (1978) called the position of the ordinary people in the news symbolic; people were there to cheer royalties or to cry in case of a severe accident, and their function was not to represent themselves, but the whole population. The growing number of stories, where the unemployed were presented more as actors than as objects in the end of the research period, hints, however, of a possibility for another journalistic culture.

Mass media continues to be important as instrument to address vast audiences and shape public and private minds. (Nordenstreng 1999). Thus, scientifically based description and assessment of media performance that traces trends of the ideological narrative of the media discourse is still needed. Overviews on content, and specifically on constructing a selected theme or time period are needed, as well as - parallel to it - monitoring of concentration and consumption and so on, for media content constitutes a strategic part of broader reasoning about the media and society. However, monitoring alone is (no matter how historical or comparative) seldom sufficient to produce more general or theoretical explanations on social phenomena. Reflecting what to monitor, how and when should be done carefully, for data itself carries no answers with it. But it can be harnessed as an aid of constructing both empirically and theoretically important questions.

\section{Notes}

1. On the other hand, HS is exceptional even internationally because of its large circulation within Finland. Suhonen $(1994,70)$ argues, that there might not be too many other newspapers that reach such a big national audience.

2. Also many studies about readers of newspapers support focusing on the headlines: newspapers are read in a glancing manner, and the headlines function as reference marks, on grounds of which decisions about reading or not reading are made (e.g., Miettinen 1980).

3. The obvious danger in constructionism and its analysis' is that the research may be reduced into a critique of different actors and their discourses. To me, it seems though, that it has not so much to do with 'facts' and their truthfulness, but the claims presented within the process of constructing the problem, and the relation of these claims with other claims and 'facts'. Therefore the solution may be found from contextualizing. By comparing the claims represented to both competing claims and other 'knowledge' about the issue, it can be understood why the claims have been brought up in the first place. By using contextual data for comparison, it is possible to ask why certain information has not been taken in the discussion etc.

4. After the second World war, the whole nation took part in the reconstruction processes, and in the 60s, economic growth was looked for with Pekka Kuusi's program, which presumed widening the participation to the labor market. In general, it has been said, that in Finland things have been tried to organize in a way that as many as possible has been working. At the same time national unity has been 
emphasized. On the other hand, it should be stressed, that this line of interpretation should be connected with longitudinal historical trends, or, as recent sociological writings (e.g., Alasuutari \& Ruuska 1999) have shown, to cultural conceptions of Finland and Finnishness. Since the 70s, in the level of political decicion-making, the pressure towards slowing down inflation has been stronger than the strive for full employment (Kosonen 1998).

\section{References}

Alasuutari, Pertti (1999) Taide, viihde, kulttuuri ja kansakunta. [Art, entertainment, culture and the nation.] In Alasuutari, Pertti \& Ruuska Petri: Post patria. Globalisaation kulttuuri Suomessa. Tampere: Vastapaino. Alasuutari, Pertti \& Ruuska, Petri (1999) Post Patria. Globalisaation kulttuuri Suomessa. (Post Patria. The Culture of Globalization in Finland.) Tampere: Vastapaino.

Altheide, David (1985) Media Power. Beverly Hills: Sage.

Altheide David \& Snow, Robert P. (1991) Media Worlds in the Postjournalism Era. New York: Aldine de Gryuter.

Anderson, Benedict (1983) Imagined Communities. London: Verso, revised edition.

Anttila, Jorma (1993) Käsitykset suomalaisuudesta - traditionaalisuus ja modernisuus. [Conceptions of Finnishness - tradition and modernity.] In Mitä on suomalaisuus? Helsinki: Suomen antropologinen seura.

Appadurai Arjun (1996) Modernity at Large. Minnesota, London: University of Minnesota Press.

Blumer, Herbert (1972) Social Problems as Collective Behavior. Social Problems 18, 298-306.

Carey, James (1989) Communication as Culture. Essays in Media and Society. London, New York: Routledge.

Curran, James (1991) in Dahlgren, Peter \& Sparks, Colin. (eds.) Communication and Citizenship. Journalism and the Public Sphere in the New Media Age. London: Routledge.

Edwards, Derek, Golding, Peter, Howitt, Dennis, McLachlan, Shelley \& MacMillan, Katie (1999) An Audit of Democracy: Media Monitoring, Citizenship and Public Policy. In Nordenstreng, Kaarle \& Griffin, Michael (eds.) International Media Monitoring. Cresskill, New Jersey: Hampton Press.

Ekecrantz, Jan (1996) Journalisms' Discoursive Events and Sociopolitical Change in Sweden 1925-87. Media, Culture \& Society, 19(3).

Ekecrantz, Jan \& Olsson, Tom (1994) Det redigerade samhället: om journalistikens, beskrivningsmakten och det informerade förnuftets historia. Stockholm: Carlsson.

Fiske, John (1992) Merkkien kieli. Johdatus Viestinnän tutkimiseen. (Introduction to Communication Studies) Tampere: Vastapaino.

Galtung, Johan (1999) Prospects for Media Monitoring: Much Overdue But Never Too Late. In Nordenstreng, Kaarle \& Griffin, Michael (eds.) International Media Monitoring. Cresskill, New Jersey: Hampton Press.

Galtung, Johan \& Vincent, R. (1992) Global Glasnost: Toward a New World Information and Communication Order. Cresskill, New Jersey: Hampton Press.

Gellner, E. (1987) Culture, Identity and Politics. Cambridge: Cambridge University Press.

Glasser, Theodor \& Craft, Stephanie (1997) Kansalaisjournalismi ja demokraattiset ideaalit. [Public journalism and democratic ideals.] Tiedotustutkimus 4.

Golding, Peter \& Middleton, Sue (1983) Images of Welfare: Press and Public Attitudes to Poverty. Oxford: Martin Robertson.

Hakkarainen, Pekka (1998) Sosiaalisten ongelmien määrittely - sosiaalisen konstruktionismin näkökulma sosiaalisiin ongelmiin. (Defining social problems - the constructionist point of view.) In Koskinen, Keijo (toim.): Sosiologisia karttalehtiä. Tampere: Vastapaino.

Hartley, John (1996) Popular Reality: Journalism, Modernity, Popular Culture. London: Arnold.

Heinonen Jari (1997) Katseita suomalaisuuteen. [Gazes into Finnishness.] Helsinki: TA-Tieto OY.

Ilmonen, Kaj (eds.) (1993) Kestävyyskoe. Kirjoituksia 1990-luvun Suomesta. [A test of endurance. Writings about Finland in the 90s.] Tampere: Vastapaino.

Julkunen Raija (1993) Onko se ohi nyt? [Is it over now?] In Haapala, Pertti (eds.) Hyvinvointivaltio ja historian oikut. Tampere: Työväen historian ja perinteen tutkimuksen seura.

Julkunen, Raija (1997) Työyhteiskunnan tulevaisuus - tosiasiat, projektit ja optiot. [The future of work centered society. Facts, projects and options.] In Kuusi esseetä työn ja työyhteiskunnan tulevaisuudesta. Valtioneuvoston kanslian julkaisusarja 5.

Kantola, Anu (1997) Tarina toisinajattelun turhuudesta. Kansallinen juhladokumentti hallinnan tekstinä. [A story of uselessness of dissidence. National documentary as a text of governance.] Tiedotustutkimus 2.

Kettunen Pauli (1997) Työjärjestys. Tutkielmia työn ja tiedon poliittisesta historiasta. [The work order. Studies on political history of work and knowledge.] Helsinki: Tutkijaliitto. 
Kiander, Jaakko (1998) Suuri lama: Suomen 1990-luvun kriisi ja talouspoliittinen keskustelu. (The great depression: the Crisis of 1990s in Finland and the economical and political debate.) Helsinki: Taloustieto.

Kivikuru, Ullamaija (1996) Tasot eivät kohdanneet. [The levels never met.] In Kivikuru (eds.) Kansa Euromyllyssä. Helsinki: Yliopistopaino.

Koistinen, Mikko (1998) Pelkkää taloutta. Retoriikka journalismin tutkimuksessa. [Bare economics. Rhetorics and studying journalism.] In Kantola \& al. (eds.) Media-analyysi. Tekstistä tulkintaan. Helsinki: Lahden tutkimus- ja koulutuskeskus.

Kosonen, Pekka (1993) Kansallisvaltio kellutuksessa. [Nation state floating.] In Ilmonen (eds.) Kestävyyskoe. Kirjoituksia 1990-luvun Suomesta. Tampere: Vastapaino.

Kunelius, Risto (1996) The News. Textually Speaking. Tampereen yliopisto: Tiedotusopin laitos.

Kunelius, Risto \& Heikkilä, Heikki (1998) Julkisen journalismin äärellä. Tiedotustutkimus 1.

Luostarinen Heikki (1993) Julkisuus: ennen kuin kansalainen katoaa. [The public sphere: Before the citizen disappears.] In Ilmonen (eds.) Kestävyyskoe. Kirjoituksia 1990-luvun Suomesta. Tampere: Vastapaino.

McNair, Brian (1996) The Sociology of Journalism. London, Sydney, New York, Auckland: Arnold.

McQuail, Denis (1999) On Evaluating Media Performance in the Public Interest: Past and Future of a Research Tradition. In Nordenstreng, Kaarle \& Griffin, Michael (eds.) International Media Monitoring. Cresskill, New Jersey: Hampton Press.

Moring, Inka (1999) Alueellinen ääni ja lamajulkisuuden kehitys. [Regional voice and the development of recession publicity.] In Moring, Parikka, Valtonen, Aslama, Kantola \& Kivikuru. Mediakriisi. Lehdistö, lama ja talouspuhe. [Media crisis. The press, the recession and the talk on economy.] Helsingin yliopisto, viestinnän laitos, sarja 2A/1/1999.

Nordenstreng, Kaarle (1999) Toward a Global Content Analysis and Media Criticism. In Nordenstreng, Kaarle \& Griffin, Michael (eds.) International Media Monitoring. Cresskill, New Jersey: Hampton Press.

Pietilä, Kauko \& Sondermann, Klaus (1994) Sanomalehden yhteiskunta. (The society of the newspaper.) Jyväskylä: Vastapaino/Gummerus.

Renvall, Mika \& Reunanen, Esa (1999) Yhteisö totuutta metsästämässä. Journalismi julkisen keskustelun kehyksenä. Community searching for the truth. Journalism as a framework of public discussion] Tiedotustutkimus 3 .

Renvall Mika \& Valtonen, Sanna (1999) Miten sosiaaliturvan väärinkäytöstä kirjoitettiin julkisuudessa? [How was misusing social security constructed in the public sphere?] In Uusitalo, Hannu (eds.) Näkökulmia sosiaaliturvan väärinkäyttöön. Helsinki: Stakes (forthcoming).

Riffe, Daniel \& Lacy, Stephen \& Fico, Frederick (1998) Analyzing Media Messages. Using Quantitative Content Analysis in Research. New Jersey and London: Lawrence Erlbaum Associates.

Schudson, Michael (1996) The Power of News. Cambridge, Massachussets, London: Harvard University Press.,

Svallfors, Stefan (1995) Välfärdsstaten i pressen. En analys av svensk tidningsrapportering om välfärdspolitik 1969-1993. Umeå Studies in Sociology, no 108.

Thompson, John (1995) Media and Modernity. A Social Theory of the Media. Cambridge, Oxford: Polity Press.

Tuchman, Gaye (1978) Making News. A Study in the Construction of Reality. New York: The Free Press.

Valtonen, Sanna (1998) Työ teksteissä, tekstit talouskriisissä. Tausta-ajatuksia mediatekstien kriittiseen analyysiin. Lisensiaatintyö. [Work within texts, texts within economic crisis.] Helsingin yliopisto: Viestinnän laitos, unpublished licenciate's thesis.

Valtonen, Sanna (1999a) Finland Online. Some Reflections on Constructing National Identity in the Media. Nordicom Information 21(4).

Valtonen, Sanna (1999) Työn ja työttömyyden tarinoita Helsingin sanomissa 1988-1997.(Stories of work and unemployment in HS 1988-1997.] In Moring, Parikka, Valtonen, Aslama, Kantola \& Kivikuru: Mediakriisi. Lehdistö, lama ja talouspuhe. Helsingin yliopisto, viestinnän laitos, sarja 2A/1/1999.

Vartiainen, Juhana (1993) Suomen talouspolitiikan vaihtoehdot 1990-luvulla. [The options of Finnish economic policy.] In Ilmonen (toim) Kestävyyskoe. Kirjoituksia 1990-luvun Suomesta. Tampere: Vastapaino,.

Vähätalo, Kari (1998) Työttömyys ja suomalainen yhteiskunta. [Unemployment and Finnish society.] Gaudeamus, Helsinki.

Väliverronen, Esa (1998) Mediatekstistä tutkijan tulkintaan. [From media text to researcher's interpretation.] In Kantola, Moring, Väliverronen (eds.) Media-analyysi. Tekstistä tulkintaan. Helsinki: Helsingin yliopiston Lahden tutkimus- ja koulutuskeskus, Helsinki.

Translations of Finnish language titles by the author. 